\title{
FOSTERING CREATIVITY OF STUDENTS WITH INTELLECTUAL DISABILITIES THROUGH MUSIC LISTENING ACTIVITIES
}

\author{
Marina Wai-Yee Wong \\ Department of Education Studies, Hong Kong Baptist University (Hong Kong SAR)
}

\begin{abstract}
This study investigates special schools music teachers' reflections on their design of music listening activities that could foster musical creativity of students with intellectual disabilities. Nine cases of special school music teachers are documented. Qualitative data were collected by classroom observations and face-to-face video elicitation interviews. The findings indicate those special school music teachers designed active listening activities that integrated with other music learning activities for enhancing students' enjoyment of music learning as well as their development of creativity and imagination.
\end{abstract}

Keywords: Music, creativity, listening activities, students with intellectual disabilities, Hong Kong.

\section{Introduction}

\subsection{Special education for students with intellectual disabilities}

In Hong Kong, students with intellectual disabilities [ID] are commonly placed in special schools according to the students' level of intellectual disabilities, i.e. mild, moderate or severe intellectual disability. All special schools in Hong Kong are funded by the government. Under the principle of "one curriculum for all", students with ID are expected to achieve the same learning targets as their counterparts in mainstream schools (Education Bureau [EDB], 2020a).

\subsection{Music curriculum for students with intellectual disabilities}

Music teachers in all special schools for children with ID are expected to implement school-based music curriculum as their counterparts in mainstream schools. Music is one of the subjects in the Arts Key Learning Area. The curriculum framework of music is laid out in the Music Curriculum Guide (Primary 1 - Secondary 3) (Curriculum Development Council [CDC], 2003). One of the overall aims of the Music Curriculum Guide (2003) is "to develop creativity, the ability to appreciate music and to effectively communicate through music" (p. 11); and one of the major learning targets is "developing creativity and imagination" (p. 12). These learning targets are expected to be achieved through listening, performing and creating activities (CDC, 2003). Music is offered as a subject to students with ID according to adapted learning objectives under the Basic Education Curriculum (Intellectual Disability) (EDB, 2020b).

\subsection{Rationale for conducting this study}

I am a music teacher educator with over 30 years of experience in teaching and supervising music teachers' practices in mainstream schools and special schools. According to my experience of working with music teachers of special schools and mainstream schools, I have the following observations: (1) Students with ID in special schools demonstrate that they are capable to learn music like their counterparts in mainstream schools; (2) Listening is an essential activity for students with ID to learn music; (2) Music teachers may have reservations in implementing creative music activities in music lessons. Thus, it is worthwhile to study how special school music teachers design listening activities to foster musical creativity of their students.

\section{Literature}

\subsection{Musical creativity}

Webster (2002) defines musical creativity as the "engagement of the mind in the process of actively structured thinking in sound for the purpose of producing some product that is new to the creator" (p. 138). When children listen to music, regardless of their intellectual ability, they may have 
their own way of thinking in sound. When they react or interact with the music they hear, they are producing sounds that are new to themselves at that moment. The development of music creativity is not age or phase dependent, it depends on the music teachers to create appropriate contexts and environment for them to develop their musical creativity (Burnard, 2006). The opportunity and time to play with music is essential in the context because their creative music making often occur in their play (Elliot, 1995).

\subsection{Teaching of musical creativity}

The practice of musical creativity in schools depends on "how teachers act, and how their students participate, how musical creativity is taught as part of school music" (Burnard, 2012, p. 9). When teachers design their curriculum for developing students' creativity, they should consider students' abilities and interests because the development of musical creativity is influenced by formal and informal instructions and prior musical experiences of the children (Burnard \& Younker, 2002). Due to the limitations of students with special needs, the availability of digital technology is an effective aid that can enhance their creativity (Adkins et al., 2013). Hong Kong special schools implement school-based adapted music curriculum (Wong, 2015). It is worthwhile to study how music lessons in special schools for students with ID to develop their musical creativity.

\subsection{Creativity in listening}

According to Peterson (2006), listener constructs mental objects and novel perception of music that correspond to music performance which differ from that of other listeners; through the creative process of attentive listening, every listening experience is new and personal, all musical sounds are new and contemporary. This perspective of recognizing music listening as a creative activity also fits Webster's (2002) definition of musical creativity. Furthermore, Hwang (2011) found that music listening combined with play can improve musical creativity skills, including musical imagination and musical originality. Thus, music listening is indispensable in developing musical creativity.

\section{Purpose of study}

Up-to-date, research about teachers' reflections on their curriculum design of listening activities for developing the musical creativity of students with ID is not found. It is worthwhile to explore and contribute in this area. The purpose of this study is to investigate special schools music teachers' reflections on the music listening activities that could foster musical creativity of students with intellectual disabilities.

\section{Methodology}

This is a qualitative multiple-case study. Purposeful sampling was used to select nine cases of special schools music teachers, three from each category of special schools for mild, moderate or severe ID. Class observation was conducted in four music lessons in each case. The choice of music lessons and level of students were left to the choice of the music teachers. All observations were conducted by the researcher. All music lessons were video recorded for viewing at the post-observation face-to-face interviews. An identical semi-structured interview guide was repeated to all nine cases. At the interview, both the teacher and the researcher could initiate discussion based on a certain incident shown in the video recording. The face-to-face video elicitation interview technique allows the researcher to prompt questions for the participants to provide in-depth clarifications about a specific incident in the video. All interview data were transcribed and checked by the participants. All data were coded, categorized and analyzed.

\section{Findings and discussion}

\subsection{Teachers' profiles and reflections}

The reflections of music teachers on their curriculum design of listening activities that could foster their students' musical creativity are presented in the following nine cases that are grouped together according to the category of children's levels of ID, i.e. mild, moderate and severe intellectual disabilities. Pseudonyms are used in reporting to ensure the anonymity of the participating teachers. Personal profiles of these nine cases are shown in Table 1. 
Table 1. Profile of the music teachers.

\begin{tabular}{|l|l|l|l|l|l|l|l|l|l|}
\hline Case & $\mathbf{1}$ & $\mathbf{2}$ & $\mathbf{3}$ & $\mathbf{4}$ & $\mathbf{5}$ & $\mathbf{6}$ & $\mathbf{7}$ & $\mathbf{8}$ & $\mathbf{9}$ \\
\hline Pseudonym & Ada & Ben & Clara & Diana & Ella & Fanny & Grace & Helen & Ivan \\
\hline Sex/Age & F/30+ & M/30+ & F/40+ & F/30+ & F/30+ & F/50+ & F/20+ & F/50+ & F/30+ \\
\hline $\begin{array}{l}\text { Type of } \\
\text { special school }\end{array}$ & \multicolumn{5}{|c|}{ Mild ID } & \multicolumn{5}{|c|}{ Moderate ID } \\
\hline Education & B. Ed & B. Mus & B. Mus & $\begin{array}{l}\text { B. Ed } \\
\text { Sp. Ed. }\end{array}$ & $\begin{array}{l}\text { B. Ed } \\
\text { Sp. Ed. }\end{array}$ & $\begin{array}{l}\text { B. Ed } \\
\text { Sp. Ed. }\end{array}$ & B. Ed. & $\begin{array}{l}\text { B. Ed. } \\
\text { Sp. Ed. }\end{array}$ & $\begin{array}{l}\text { B.A. } \\
\text { (Mus) }\end{array}$ \\
\hline Music ed. & $\checkmark$ & $\checkmark$ & $\checkmark$ & $\checkmark$ & $\checkmark$ & $\checkmark$ & x & x & $\checkmark$ \\
\hline $\begin{array}{l}\text { Years of } \\
\text { teaching }\end{array}$ & $\begin{array}{l}>10 \\
\text { years }\end{array}$ & $\begin{array}{l}>10 \\
\text { years }\end{array}$ & $\begin{array}{l}>15 \\
\text { years }\end{array}$ & $\begin{array}{l}>10 \\
\text { years }\end{array}$ & $\begin{array}{l}>15 \\
\text { years }\end{array}$ & $\begin{array}{l}>25 \\
\text { years }\end{array}$ & $\begin{array}{l}<5 \\
\text { years }\end{array}$ & $\begin{array}{l}>25 \\
\text { years }\end{array}$ & $\begin{array}{l}>10 \\
\text { years }\end{array}$ \\
\hline
\end{tabular}

Summary information of the selected classes, observed learning activities and summary of teachers' reflections are illustrated in Table 2.

Table 2. Information of selected classes, observed learning activities and teachers' reflections.

\begin{tabular}{|c|c|c|c|}
\hline Case & $\begin{array}{l}\text { Age/ } \\
\text { No. of } \\
\text { students }\end{array}$ & $\begin{array}{l}\text { Observed } \\
\text { listening activities }\end{array}$ & Summary of reflections \\
\hline Amy & $\begin{array}{l}\text { Age 6-8/ } \\
7 \text { students }\end{array}$ & $\begin{array}{l}\text { Listen to music with } \\
\text { music movements }\end{array}$ & $\begin{array}{l}\text { Facilitate students to create music-induced movements } \\
\text { to express the loud and soft dynamic levels of the songs. } \\
\text { Show students' imagination of the relationship } \\
\text { between the dynamic changes of music. }\end{array}$ \\
\hline Ben & $\begin{array}{l}\text { Age } 12-14 / \\
5 \text { students }\end{array}$ & $\begin{array}{l}\text { Explore \& mixing } \\
\text { melodic fragments \& } \\
\text { sound effects with IT } \\
\text { apps }\end{array}$ & $\begin{array}{l}>\text { Listening to students' own works can develop their } \\
\text { awareness of the sounds of their works. } \\
>\text { Listening to classmates' work can stimulate students } \\
\text { to create more. } \\
>\text { My feedbacks guide them to analyze the musical } \\
\text { features that made up those sound effects. ... help them } \\
\text { to organize their imagination of sounds in their minds } \\
\text { and decide on the sounds in their works. }\end{array}$ \\
\hline Cara & $\begin{array}{l}\text { Age } 12-14 / \\
14 \text { students }\end{array}$ & $\begin{array}{l}\text { Listen to music with } \\
\text { music movements }\end{array}$ & $\begin{array}{l}>\text { Familiarize them with the music by repeated listening } \\
\text { and watching the music video. ... they may imitate the } \\
\text { movements of the dancers, musicians and conductor. } \\
>\text { Watching music video can enrich their imagination for } \\
\text { creative movement and musical expressions. }\end{array}$ \\
\hline Diana & $\begin{array}{l}\text { Age } 12-14 / \\
10 \text { students }\end{array}$ & $\begin{array}{l}\text { Explore \& rearrange } \\
\text { sounds with IT apps }\end{array}$ & $\begin{array}{l}\text { Students worked in groups to explore and listen to the } \\
\text { effects of single sound track and mixing sound tracks. } \\
\text { They were so happy to hear the new sounds and enjoy } \\
\text { their collaborative music arrangement. } \\
>\text { The use of IT apps facilitates them to create sounds. }\end{array}$ \\
\hline Ella & $\begin{array}{l}\text { Age } 12-14 / \\
8 \text { students }\end{array}$ & $\begin{array}{l}\text { Listen to music with } \\
\text { creative movements \& } \\
\text { paper models of } \\
\text { instruments }\end{array}$ & $\begin{array}{l}\text { The use of paper models of Chinese instruments } \\
\text { facilitated my students to participate actively and } \\
\text { creatively while listening to Chinese music. } \\
\text { They created music movements with the paper } \\
\text { models. They showed their imaginations and their } \\
\text { interactions with the music excerpts. Their movements } \\
\text { responded to the music features, such as loud/soft and } \\
\text { fast/slow of the music excerpts very well. }\end{array}$ \\
\hline
\end{tabular}




\begin{tabular}{|c|c|c|c|}
\hline Fanny & $\begin{array}{l}\text { Age 9-11/ } \\
9 \text { students }\end{array}$ & $\begin{array}{l}\text { Watch \& listen to } \\
\text { students' performance } \\
\text { and create movements } \\
\text { and percussion } \\
\text { accompaniment }\end{array}$ & $\begin{array}{l}>\text { My students enjoyed watching their group singing } \\
\text { performance. It motivated them to create movements } \\
\text { and percussion accompaniment. } \\
>\text { Listening activities are especially important for } \\
\text { nonverbal and verbally weak students to stimulate their } \\
\text { creativity through their movements and percussion } \\
\text { accompaniment. }\end{array}$ \\
\hline Grace & $\begin{array}{l}\text { Age 9-11/ } \\
3 \text { students }\end{array}$ & $\begin{array}{l}\text { Listen to music with } \\
\text { creative movements and } \\
\text { accompany with } \\
\text { percussion instruments }\end{array}$ & $\begin{array}{l}\text { Listening to music can stimulate my students' } \\
\text { creativity when they react with music. I adapted } \\
\text { instruments to fit their physical ability and I adapted the } \\
\text { music excerpts to include some blank moments between } \\
\text { sections for them to create sounds. } \\
\text { They were excited and move more when listening to } \\
\text { music with stronger beats and festival moods. } \\
\text { They enjoyed creating movements and sounds while } \\
\text { listening to music. It's important to develop their } \\
\text { creativity as well as autonomy through listening activity. }\end{array}$ \\
\hline Helen & $\begin{array}{l}\text { Age 12-14/ } \\
2 \text { students }\end{array}$ & $\begin{array}{l}\text { Listen to music with } \\
\text { creative movements }\end{array}$ & $\begin{array}{l}\text { Military march could motivate my students to react } \\
\text { creatively. } \\
\text { Their hands were too weak to make any sound on a } \\
\text { real drum. The use of mobile apps can help them to play } \\
\text { electronic drums by touching the screen softly. } \\
>\text { The use of recorder pen to play music near their ears } \\
\text { can help students with hearing impairment to listen more } \\
\text { clearly and attentively. }\end{array}$ \\
\hline Ivan & $\begin{array}{l}\text { Age } 9-11 / \\
8 \text { students }\end{array}$ & $\begin{array}{l}\text { Explore sound effects } \\
\text { with instruments or IT } \\
\text { apps }\end{array}$ & $\begin{array}{l}>\text { Different versions of remixing a piece of music may } \\
\text { enrich their imagination and stimulate them to explore } \\
\text { new sounds. } \\
>\text { The use of iPads and Makey Makey could help them } \\
\text { to overcome their disabilities when exploring and } \\
\text { creating new sounds while listening to music. } \\
>\text { Record the sounds they made and show it to the class } \\
\text { can encourage their imagination. They enjoy listening to } \\
\text { their own work as well as their classmates' work. }\end{array}$ \\
\hline
\end{tabular}

\subsection{Listening activities for fostering musical creativity}

Drawing from the above summary of teachers' reflections, they regard their designs of listening activities as a way to foster musical creativity. Due to the physical and cognitive limitations of the students with ID, music teachers had to design active listening activities to engage students for students to demonstrate their music learning outcomes of music listening and creating. These active listening activities are often integrated with other activities so as to make it meaningful and interesting for students. These activities include (1) music-induced movements that allow students to exercise their musical creativity; (2) formative assessment activities such as self-assessment that allow students to review their own creative work and peer assessment that allow students to appreciate their peer's work. The choice of music repertoire and proper teaching aids (such as paper models, mobile apps and music technology) for listening activities are also crucial for helping students with ID to develop their imagination and awareness of sounds which are essential in musical creativity.

\section{Conclusion}

Special school music teachers' reflections demonstrate that they designed active listening activities that integrated with other music learning activities, such as music movements, music creating activities and formative assessment activities such as self-assessment and peer assessment. In addition, the choice of music repertoire and teaching aids to suit the abilities and interests of students is also important for students' enjoyment of music learning as well as their development of creativity and imagination. 


\section{References}

Adkins, B., Summerville, J., Knox, M., Brown, A. R., \& Dillon, S. (2013). Digital technologies and musical participation for people with intellectual disabilities. New Media \& Society, 15(4), 501-518. https://doi.org/10.1177/1461444812457338

Burnard, (2012)

Burnard, P. (2006). Understanding children's meaning-making as composers. In I. Deliege \& G. A. Wiggins (Eds.), Musical creativity. Multidisciplinary research in theory and practice (pp. 111-133). Hove: Psychology Press.

Burnard, P., \& Younker, B. (2002). Mapping pathways: Fostering creativity in musical composition. Music Education Research, 47, 60-74.

Curriculum Development Council [CDC] (2003). Music Curriculum Guide (Primary 1 - Secondary 3). Retrieved April 14, 2020, from: https:/www.edb.gov.hk/attachment/en/curriculumdevelopment/kla/arts-edu/references/music\%20complete\%20guide_eng.pdf

Education Bureau [EDB] (2020a). Special Educational Needs. Retrieved April 14, 2020, from https://www.edb.gov.hk/en/curriculum-development/major-level-of-edu/special-educationalneeds/index.html

Education Bureau [EDB] (2020b). Basic Education Curriculum. Retrieved April 14, 2020, from https://www.edb.gov.hk/en/curriculum-development/major-level-of-edu/special-educationalneeds/basic-edu-curriculum/index.html

Elliott, D. J. (1995). Music matters: A new music philosophy of music education. New York: Oxford University Press.

Hwang, E. (2011). The effects of music listening with play on preference, recognition of the main melody and musical creativity in elementary school students. Voices: A World Forum for Music Therapy, 11, Np. Retrieved April 14, 2020 from https://voices.no/index.php/voices/article/view/1967/1708

Peterson, E. M. (2006). Creativity in Music Listening. Arts Education Policy Review, 107(3), 15-21, DOI: 10.3200/AEPR.107.3.15-21

Webster, P. R. (2002). Creative thinking in music: Advancing a model. In T. Sullivan \& L. Willingham (Eds.), Creativity and Music Education (pp. 16-34). Edmonton: Canadian Music Educators' Association.

Wong, M. W.-y. (2015). Adapting the music curriculum for senior secondary students with intellectual disabilities in Hong Kong: content, pedagogy and mindsets. Music Education Research, 17(1), 71-87. 